Timişoara Physical Education and Rehabilitation Journal

DOI: 10.2478/tperj-2013-0014

\title{
Study on the psycho-motor profile of the central defender in Romanian football compared to European football
}

\section{Sorin BRÎNDESCU1}

\begin{abstract}
The stage reached nowadays in the development of the game of football throughout the world, as a result of the effort and concern of specialists and players for continuous improvement of the game, inevitably led to the development of new well-established ideas and solutions about the manner of playing, the game and training system, the selection and promotion of players. All this made the performance level be very high at present, both nationally and especially internationally, and this can only be achieved by players whose performance capacity is particularly large and growing. A special contribution in solving these problems has been brought and will be brought further by scientific research, both the fundamental one which studies essentially the mass basis of performance football in all its conceptual complexity, and the applicative one which addresses more limiting issues but still definite, specific to the practice and methodology of football at this level. Moreover, until now there have been numerous studies with an applicative nature joined by many specialists worldwide through research studies conducted over the years. Thus, it can be appreciated that most of the issues regarding the effective contact time with the ball are identified by the manner in which the possession of the ball is gained and lost. Therefore, we compared the two competitions, the players involved, depending on their position in a team. We want the results to be mostly a support for the advanced training of football players at all divisionary levels, with the possibility of achieving specific training plans and stages.
\end{abstract}

Key words: psycho-motor profile, central defender, First League, European competitions

\section{Rezumat}

Stadiul atins în prezent de evoluţia jocului de fotbal pe plan mondial, ca rezultat al efortului şi preocupării specialiştilor şi jucătorilor pentru continua perfecţionare a jocului a dus inevitabil la conturarea unor idei şi soluţii noi, precis stabilite, cu privire la maniera de a juca, la sistemul de joc şi de pregătire, la selecţia şi promovarea jucătorilor. Toate acestea au făcut ca nivelul performanţelor în etapa actuală atât în plan naţional, dar mai ales în plan internaţional, să fie foarte ridicat şi să nu poată fi atins decât de jucătorii a căror capacitate de performanţă este deosebit de mare şi în continuă creştere. O contribuţie deosebită în rezolvarea acestor probleme şi-a adus-o şi o va aduce în continuare cercetarea ştiinţifică atât cea fundamentală, care studiază baza de masă a fotbalului de performanţă în toată complexitatea ei conceptuală, în esenţă, cât şi cea aplicativă, care abordează aspecte mai limitative, dar concrete, specifice practicii şi metodicii fotbalului la acest nivel. Mai mult chiar, până în prezent au fost efectuate numeroase studii cu caracter aplicativ, la care au aderat mulţi specialişti în domeniu din lumea întreagă, prin studii şi cercetări efectuate de-a lungul anilor. Astfel, se poate aprecia că cea mai mare parte a problematicii timpului efectiv de contact cu mingea, se identifică cu maniera în care se câştigă şi se pierde posesia mingii. Astfel, dorim o comparaţie între cele două competiţii, între jucătorii ce activează în cadrul lor, în funcţie de postul ocupat în echipă. Ne dorim ca rezultatele obţinute să constituie în primul rând un sprijin în instruirea avansată a jucătorilor de fotbal, la orice nivel divizionar, existând posibilitatea de realizare a planurilor şi etapelor de pregătire specifice.

Cuvinte cheie: profil psiho-motric, fundaş central, Prima Ligă, Competiţii Europene

${ }^{1}$ Lecturer PhD, West University of Timișoara, Faculty of Physical Education and Sports, e-mail: sorin.brindescu@e-uvt.ro 
Timisoara Physical Education and Rehabilitation Journal

\section{Introduction}

In promoting football as a super-competition a great importance has the technical training, which increasingly felt the infiltration of reasoning, the logic, because each game takes place according to a different tactical scheme, which requires appro-priate technical means and which ultimately requires scientific preparation [1].

Forming a technique can not only rely on learning some movements but we must take into account the conditions implied by the football game. In this respect the internal logic of the game showed that the most appropriate are the pressing exercises, those made at a higher tempo, those made in small spaces but also those offering solutions to more complex game situations. However, the technical training does not form a player, so the technical training must always be carried out in relation to the individual play [2].

A global study highlights the fact that the research carried out by many experts on various websites shows that it becomes increasingly difficult to obtain high marks in evaluating a player. The psycho-motor profile includes many terms of characterization of different positions. As already known, each position on the field has features common to all position and features characteristic to that post only [3].

Thus we want that, by creating a statistical study from a technical-tactical, physical and psychological point of view on the psycho-motor profile of players operating in the central defender position in the First League compared to other defenders of stronger European football championships in the competitive year 2012-2013, to obtain data with a positive role in order to increase the amount of the competitive value of the players, the game's effectiveness and efficiency in domestic football.

\section{The purpose}

The purpose of this paper is to investigate how the internal logic of the game evolved in important national football teams, and for making this investigation we must analyze the psycho-motor profile of players in the central defender position. This analysis can be traced from different perspectives, but the most suitable for the purpose of this paper is the statistical, technical-tactical and psychological comparative analyses, because it helps us to underline the structural novelties that make the difference.
We believe that such an analysis will help us to understand the organization of the game in highperformance teams, and especially the direction this sport is heading nationally.

\section{Method}

For this comparative statistical, technical, tactical and psychological study resulting in studying the psychomotor profile of players in the central defender position in the First League and in other European football championships, the following steps have been taken:

- Choosing a number of central defenders (10 subjects) playing for teams in the First League championships in the competitive year 20122013. For objective reasons, we have chosen randomly to avoid major influence in the results of the study;

- Choosing a similar number of central defenders playing for teams from strong leagues in Europe. In this case we chose players playing for teams in the UEFA Champions League and UEFA League in the competitive year 2012-2013.

- Establishing scientifically the components of a psycho-motor profile of the central defender and systematizing them on a technical sheet.

Statistical evaluation in terms of the psycho-motor profile has the following criteria of comparison:

- height, weight, base leg

- mistakes in the game, discipline in the game

- head game

- placement in each phase of the game

- speed: reaction, execution and movement

- force

- percentage of dispossession of the ball, safe passing

- kicks on goal, obviously emerging in strike phase counts

- permanence in competition

- market value, which summarizes the above

- yellow and red cards received

- Championship games

- European Cups games

- other cups games

- National team games

\section{Results}

If we consider the results obtained, isolated on each criterion, the conclusion is that we can compare ourselves with many European champion- 
ships. However if we look at the whole, considering all the comparison components between the central defenders involved in the study, the situation changes. The large number of games and the level of competitions in which the subjects play, significantly change the interpretation of the data. A noteworthy fact is that in this study marks were obtained in the competition where the subject played. So we consider that a real assessment can be made only if all subjects would play in the same competition. Therefore the market value is the only one able to briefly characterize a player, regardless of the position he plays.
The hypothesis of this paper was confirmed by the data obtained, the results being, in our opinion, a mirror of the game and of the value of the central defenders in the First League Championship.

We believe that the subjects in the First League followed throughout this study could be playing in more powerful championship, of course not necessarily in top teams. Perhaps an important role has the psychological factor. Many players in the First League have a wide range of technical and tactical skills with the ball, but are not able to apply them in the game - thus resulting in the reduced or inadequate number of technical executions.

The study achieved its objectives, which are to show for real where the Championship of the First League stands, in terms of the value of its players.

Table I. Arithmetic averages recorded on the main features tested I

\begin{tabular}{ccc}
\hline & European defenders & First League defenders \\
\hline Age & 27.4 & 26.3 \\
Height & 187.8 & 186.0 \\
Weight & 78.7 & 79.2 \\
\hline Foot & $\mathrm{R}$ & $\mathrm{R}$ \\
\hline Mistakes in the game & 5.9 & 5.8 \\
\hline Discipline in the game & 6.2 & 6.2 \\
Head game & 7.3 & 6.3 \\
\hline Location on phase of game & 7.0 & 6.4 \\
\hline
\end{tabular}

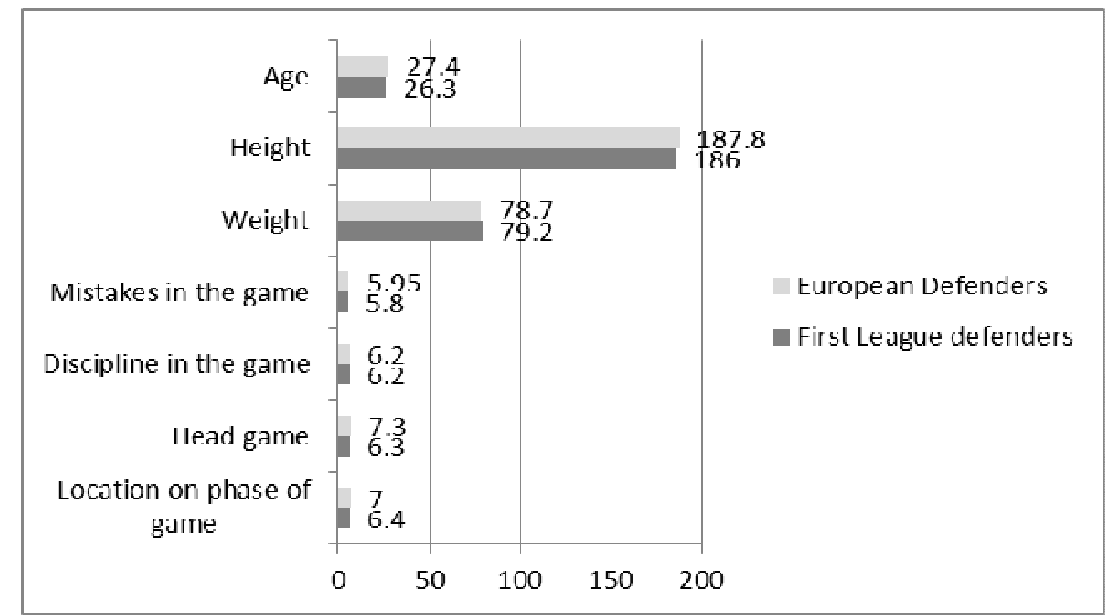

Figure 1. Arithmetic averages recorded on the main features tested I

The table I shows that the average of the ages of the subjects in the First League is lower - 26.3 years, whereas the size of defenders in European championships is bigger $187.8 \mathrm{~cm}$. The average weight is higher for First League defenders -79.2 $\mathrm{kg}$. As for the foot kicking the ball we state that the right one is predominant, two players kick with the left foot and one is recognized as ambidextrous with good ball kicking performance.

According to the ratings obtained for the mistakes in the game, the group from other European leagues has a higher average -7.95, as it is in the head game -7.3 and in the location on phase of game -7.0. As for the discipline in the game the calculated arithmetic averages are equal - 6.2. 
Timisoara Physical Education and Rehabilitation Journal

Table II. Arithmetic averages recorded for the main features tested II

\begin{tabular}{lcc} 
& European defenders & First League defenders \\
\hline Speed & 6.5 & 6.2 \\
\hline Force & 7.1 & 6.3 \\
\hline Stripping the ball & 7.1 & 6.4 \\
\hline Safety in passing the ball & 5.9 & 5.8 \\
\hline Shot on goal & 5.7 & 5.2 \\
\hline Continuity in competition & 6.9 & 6.3 \\
\hline The market value & 22.9 & 1.5 \\
\hline
\end{tabular}

Thus, the average ratings for speed and force are higher for the group of players in the European Championships compared with the group in the First League -6.5 and 7.1 respectively. Stripping shows a bigger difference between the averages, 7.1 for the group of players in the European Championships versus 6.4 for the group in the First League. Safety in passing the ball has closer values - 5.9 vs. 5.8 . Continuity in competition meets several traits, starting with taking the competition seriously and ending with localization and the necessity of showing up in a team. The average is higher for the group of players in the European Championships League, 6.9 compared to 6.3 for the group in the First League. The market value shows a great difference between average values - 22.9 million euro for the group of players in the European Championships League against 1.5 million euro for the 2nd group.

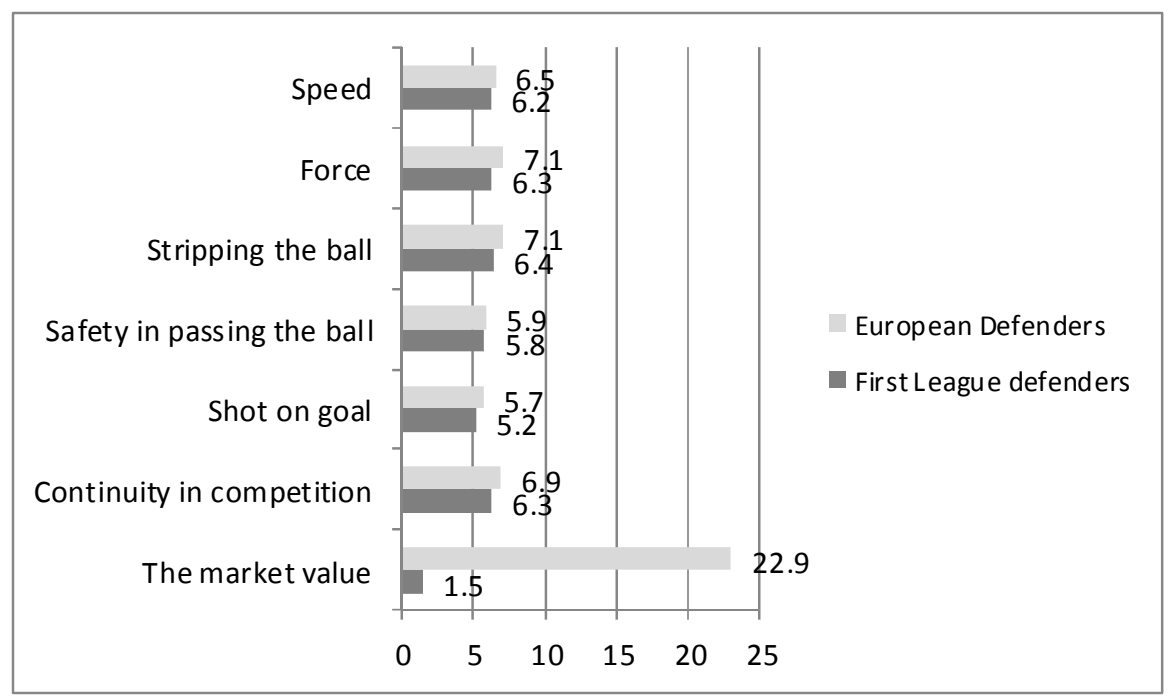

Figure 2. The graphical representation of arithmetic averages recorded for the main features tested II

Table III. Arithmetic averages of the number of games and goals scored in the followed competitions for the groups studied

\begin{tabular}{lcc}
\hline & European defenders & First League defenders \\
\hline Championship games 2012-2013 & 24.5 & 24.5 \\
\hline Games in European Cups 2012-2013 & 8.7 & 2.9 \\
\hline Games in other Cups 2012-2013 & 5.5 & 2.0 \\
\hline Games for the National Team 2012- & 3.3 & 1.7 \\
2013 & 2.2 & 2.2 \\
\hline Goals in championship 2012-2013 & 1.6 & 0.4 \\
\hline Goals in European Cups 2012-2013 & 1.6 & 0.4 \\
\hline Passing on goal & & \\
\hline
\end{tabular}

National championship games averages for each subject are equal - 24.5. However the situation 
changes for games in international competitions, with a great advantage for the European championships group of players. Thus in the European Cups the ratio is 8.7 to 2.9 , in other cups 5.5 to 2.0 , in games for the National Team 3.3 to 1.7 for goals in national championships averages are equal - 2.2 , the differences are noticeable for goals in European competitions -1.6 compared to 0.4 . The same ratio can be also found in passing on goals in all the competitions the subjects played in, that is 1.6 versus 0.4 for the group of central defenders in the First League.

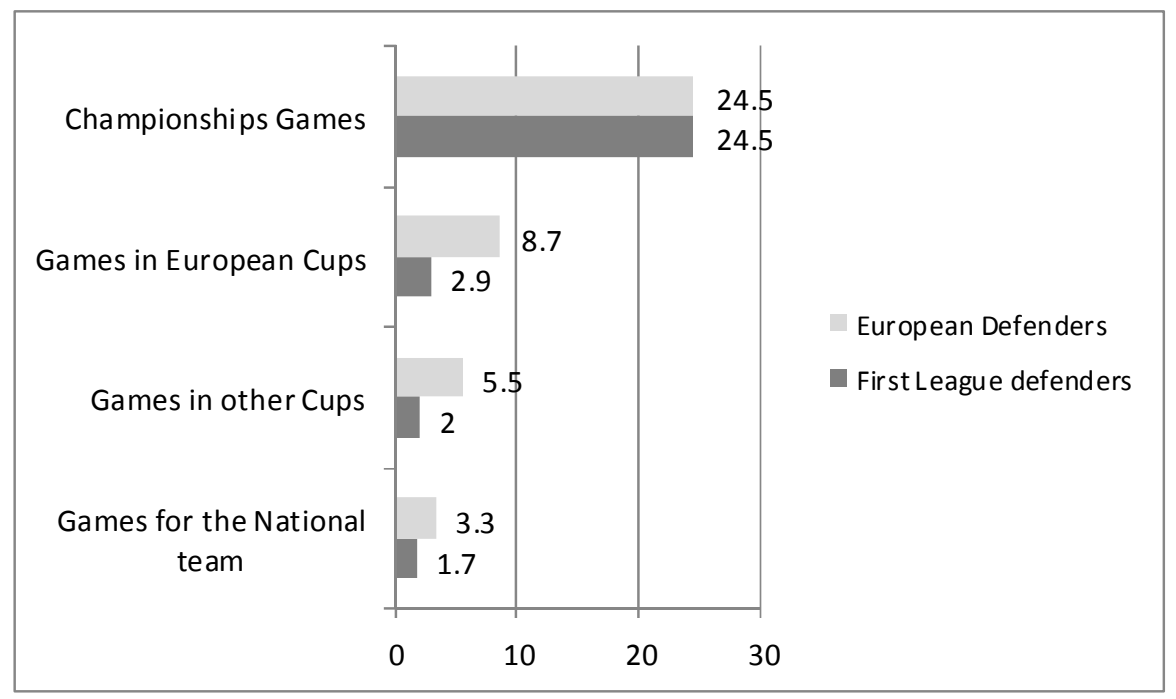

Figure 3. Graphical representation of the arithmetic averages of the number of games played by the groups tested in the competitions followed

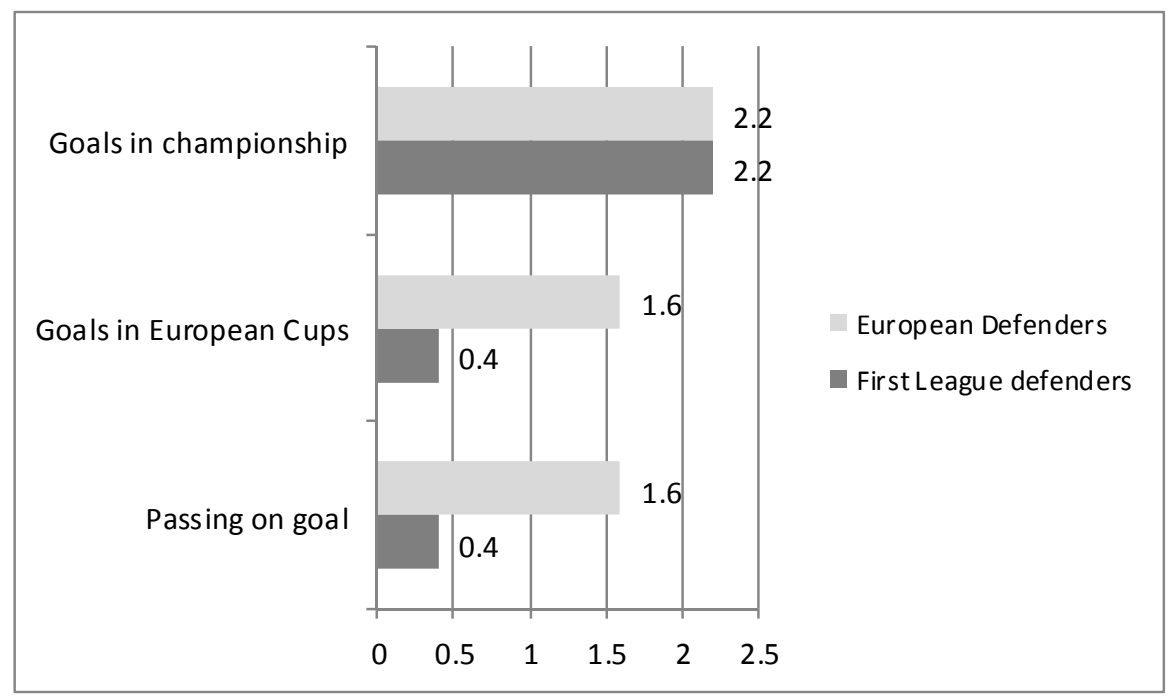

Figure 4. Graphical representation of the arithmetic averages of the goals scored by the groups tested in the competitions followed

\begin{tabular}{cccc}
\multicolumn{4}{c}{ Table IV. Arithmetic averages of the number of cards received in the competitions followed for the studied groups } \\
\hline \multirow{3}{*}{ Yellow cards } & Championship 2012-2013 & European defenders & First League defenders \\
\cline { 2 - 4 } Red cards & European Cup 2012-2013 & 4.1 & 5.9 \\
\cline { 2 - 3 } & Championship 2012-2013 & 3.6 & 0.9 \\
\hline
\end{tabular}


Another criterion for comparison of the central defenders is the number of cards received for various mistakes or fouls or misconduct to the referee or opponent. Regarding the yellow cards, it is noted that in the championship the defenders in the First League had a higher average -5.9 to 4.3. On the other hand in the European competitions the difference is bigger, 3.6 to 0.9 , due to a reduced number of games played. The same ratio appears as far as the red cards are concerned: in the championship the average is 0.5 and 0.4 and in the Cups 0.3 and 0 , the latter values being for the group in the First League.

The total number of games each subject had and on the basis of which this study was conducted presents an average of 41.3 games for the group of players in the European Championships, which are more powerful, and $\mathbf{3 0 . 5}$ for the group in the First League. There is a $25 \%$ difference, considerable in this study.

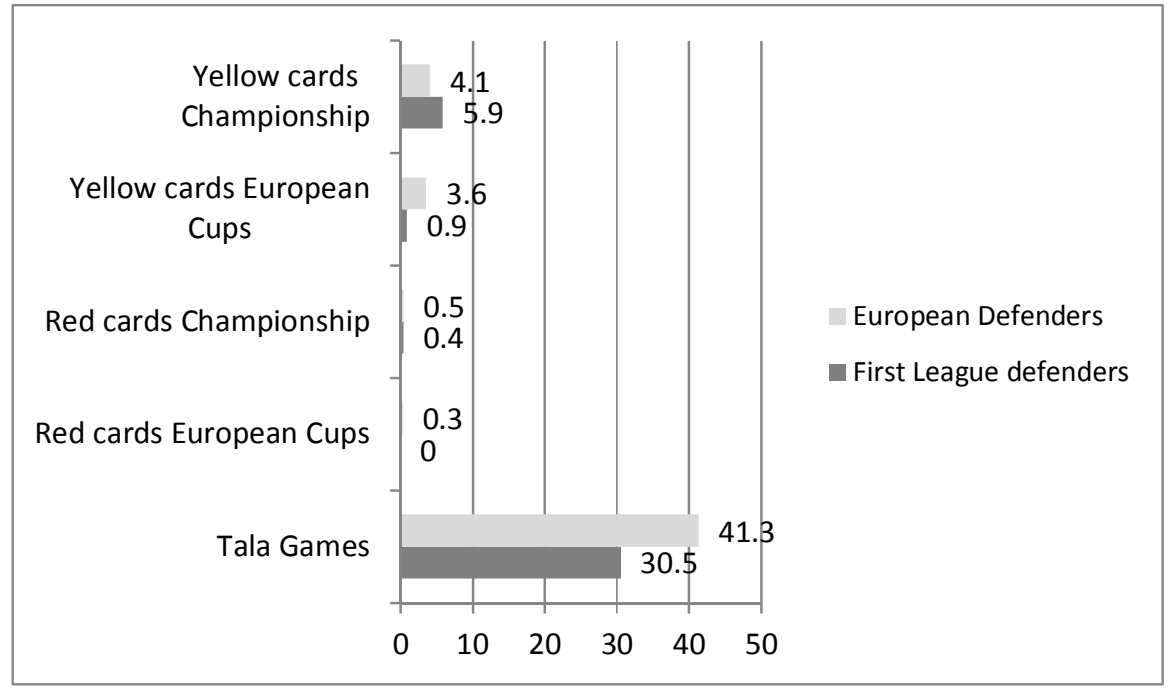

Figure 5. Graphical representation of the arithmetic averages of the cards received in competitions followed for the groups studied

\section{Conclusions}

- If we consider the marks obtained, isolated on each criterion, the conclusion is that we can compare our players with many European championships. However if we look at the whole, considering all the comparison components between the central defenders involved in the study, the situation changes. The great number of games held, together with the level of the competitions significantly changes the interpreting of the data.

- A noteworthy fact is that in this study the marks were obtained in the competition where the subject studied played. Thus we consider that a real assessment can be made only if all subjects would play in the same competition. Therefore the market value is the only one able to briefly characterize a player, regardless of the position he plays.

- We believe that the subjects of our study that play in the First League could play in stronger championships, of course not for top teams. Perhaps an important role of belongs to the psychological factor. Many players in the First League have a wider range of technical and tactical skills with the ball, but are not able to apply them in the game - thus resulting in a reduced or inadequate number of technical executions.

- The study achieved its objectives, which were to show where the Championship of the First League really is, in terms of value of its players.

\section{References}

1. Gârleanu D. (2005) Selecții pentru dezvoltarea calităților motrice la fotbalişti Editura Sport-Turism, Bucureşti, pag. 171

2. Neța G. (2008), Strategia performanței în fotbal, Editura Dacia, Cluj-Napoca, pag. 96

3. Niculescu M., Vladu L. (2009) Performanța sportivă, Editura Universitaria, Craiova, pag. 123. 